\title{
Energetic, Economic and Environmental Evaluation of Internal Combustion Engines Technologies Used in Brazilian Road Cargo Transportation
}

\section{Eyko Medeiros Rios}

CEFET/RJ: Centro Federal de Educacao Tecnologica Celso Suckow da Fonseca

Cristina Gomes de Souza

CEFET/RJ: Centro Federal de Educacao Tecnologica Celso Suckow da Fonseca

\section{Valter Silva}

IPP: Instituto Politecnico de Portalegre

Ronney Arismel Arismel Mancebo Boloy ( $\square$ ronney.boloy@cefet-rj.br)

CEFET/RJ: Centro Federal de Educacao Tecnologica Celso Suckow da Fonseca https://orcid.org/00000002-4774-8310

\section{Research Article}

Keywords: Biofuels, dual fuel mode, energy-ecological efficiency, economic estimative

Posted Date: February 4th, 2022

DOI: https://doi.org/10.21203/rs.3.rs-1208506/v1

License: (9) This work is licensed under a Creative Commons Attribution 4.0 International License.

Read Full License 

Eyko Medeiros Rios ${ }^{1[0000-0002-6673-415 X]}$, Cristina Gomes de Souza ${ }^{1[0000-0002-8996-8768]}$, Valter Silva ${ }^{20000-0003-}$
and Ronney Arismel Mancebo Boloy

${ }^{1}$ Centro Federal de Educação Tecnológica Celso Suckow da Fonseca, Rio de Janeiro, Brazil

${ }^{2}$ Instituto Politécnico de Portalegre, Brazil

Corresponding author: ronney.boloy@cefet-ri.br

\section{$1.1 \quad$ Funding}

The Brazilian Coordination for the Improvement of Higher Education Personnel (CAPES), FINANCE CODE:001 and the Brazilian National Council for Scientific and Technological Development (CNPq) with the project, title in Portuguese "Misturas Biogás-Biodiesel utilizadas em sistemas de injeção dualfuel dos Motores de Combustão Interna a Compressão" [406789/2018-5]

\subsection{Conflicts of interest/Competing interests}

All authors have participated in (a) conception and design, or analysis and interpretation of the data; (b) drafting the article or revising it critically for important intellectual content; and (c) approval of the final version. This manuscript has not been submitted to, nor is under review at, another journal or other publishing venue. The authors have no affiliation with any organization with a direct or indirect financial interest in the subject matter discussed in the manuscript.

\subsection{Availability of data and material}

Not applicable.

\subsection{Code availability}

Not applicable.

\subsection{Authors' contributions}

Eyko Medeiros Rios: Conceptualization, Methodology, Investigation, Formal analysis, Writing Original Draft and Visualization.

Ronney Arismel Mancebo Boloy, Cristina Gomes de Souza, Valter Silva: Conceptualization, Methodology, Investigation, Formal analysis, Supervision and Project Administration.

\subsection{Ethics approval}

Not applicable. 


\title{
1.7 Consent to participate
}

Not applicable.

\subsection{Consent for publication}

The authors give consent for the publication of details within the text to be published in the Journal.

\begin{abstract}
This study presents a comprehensive energetic (thermal efficiency, mass flow rate), economic (environmental cost of the life cycle) and environmental (ecological efficiency) analysis that was carried out to promote the possible replacement of the conventional internal combustion engine operation mode by ignition compression with the dual fuel mode, promoting the use of biofuels, namely: biodiesel, biogas and hydrogen in the proportion of $70 \%$ when applied to road cargo transportation. Three methods; energetic analysis, environmental life cycle costing assessment and ecological efficiency are used to obtaining the highest economic profitability from the alternative fuels with the minimum environmental impact for Brazilian road cargo transportation. A truck model delivery 6.160 Volkswagen is selected as the case study. The values of mass flow rate, thermal efficiency, environmental cost of the life cycle and ecological energy efficiency were estimated using their respective equations and indicators. The energetic analysis showed values of mass flow rates for biodiesel+hydrogen and biodiesel+biogas, equals to $6.45 \mathrm{~kg} / \mathrm{h}$ and $26.94 \mathrm{~kg} / \mathrm{h}$ respectively, and for conventional diesel of $33.88 \mathrm{~kg} / \mathrm{h}$. In the economic analysis, an environmental life cycle cost equal to $10.21 \mathrm{R} \$ / \mathrm{km}$ was obtained for biodiesel + hydrogen produced through electrolysis with photovoltaic energy,5.10 R \$ / km for biodiesel + Hydrogen produced through electrolysis with wind energy, $2.83 \mathrm{R} \$ / \mathrm{km}$ for biodiesel + Hydrogen produced through methane steam reforming without CCUS, $3.02 \mathrm{R} \$ / \mathrm{km}$ for biodiesel + Hydrogen produced through biomass gasification, $3.98 \mathrm{R} \$ / \mathrm{km}$ for biodiesel + biogas and $2.11 \mathrm{R} \$ / \mathrm{km}$ for diesel scenarios. Finally, in environmental analysis, the energy-ecological efficiency achieved for the operating modes of diesel, biodiesel + biogas and biodiesel + hydrogen were $32.2 \%, 52 \%$ and $64 \%$ respectively. Considering the results found, it is pertinent to highlight that the most promising scenario is for the use of the biodiesel + hydrogen produced from biomass gasification proportions, which achieved greater efficiency, lower long-term cost and emissions close to zero greenhouse gases, however, it is still an expensive technology and worthy of attention, government plans and guidelines to become a competitive alternative in the market for biofuels and environmentally friendly technologies.
\end{abstract}

Keyword Keys: Biofuels, dual fuel mode, energy-ecological efficiency, economic estimative. 
Brake Power

VE

Volumetric Efficiency

TE

Thermal Efficiency

EGT

Exaustion Gas Temperature

CA

Crank Angle

BFR

Biogas Flow Rate

FR

Fuel Replacement

GFR

Gas Fuel Rate

DFR

Diesel Fuel Rate

MFB

FFR

Mass Fraction Burnt

ID

Fuel Flow Rate

Ignition Delay

CP

Cilinder Pressure

HRR

Heat Release Rate

CD

Combustion Duration

$\mathrm{CO}$

Carbon monoxide

$\mathrm{CO} 2$

Carbon Dioxide

$\mathrm{HC}$

Hydrocarbon

NOx

Nitrogen Oxide

SO

Smoke Opacity

$\mathrm{CH} 4$

Methane

$\mathrm{UHC}$

$\mathrm{PM}$

$\mathrm{CH} 2$

$\mathrm{H} 2$

LCA

BG

Unburnt Hydrocarbon

Particulate Mattter

Methylene

Hydrogen

Life Cycle Assessment

Biogas

BD

Biodiesel

$\mathrm{CNG}$ 


$\begin{array}{lc}\text { LNG } & \text { Liquid Natural Gas } \\ \text { NG } & \text { Natural Gas } \\ \text { LFG } & \text { Liquified Petroleum Gas } \\ \text { CI } & \text { Compression Ignition } \\ \text { SI } & \text { Spark Ignition } \\ \text { ON } & \text { Octane Number } \\ \text { HCCI } & \text { Homogenous charge compression ignition } \\ \text { SCCI } & \text { Stratified Charge Compression Ignition } \\ \text { EGR } & \text { Exhaust Gas Recirculation }\end{array}$

81

82 ABBREVIATIONS

83

84 1.4-DCB 1.4-Diclobenzeno

85 ABNT Brazilian Association of Technical Standards

86 ANP National Agency of Oil, Natural Gas and Biofuels

87 BD Biodiesel

88 BEN National Energy Balance

$89 \quad$ BG Biogas

90 BioG Biomass Gasification

91 BP Brake Power

92 BTE Brake Thermal Efficiency

$93 \mathrm{C}_{18} \mathrm{H}_{32} \mathrm{O}_{2} \quad$ Biodiesel

$94 \quad \mathrm{C}_{6} \mathrm{H}_{6} \quad$ Diesel

95 CCUS Carbon Capture Utilisation and Storage

$96 \mathrm{CH}_{4} \quad$ Methane

97 CI Compression Ignition

98 CIE Compresion ignition engine

99 CNG Compressed Natural Gas 
CNT National Transport Confederation

$101 \mathrm{CO}$

Carbon monoxide

$102 \mathrm{CO}_{2}$

Carbon Dioxide

103

DFM

Dual Fuel Mode

104

105

EGR

Exhaust Gas Recirculation

106

eLCC Environmental life cycle costing

$107 \quad \mathrm{EPE}$

Energy research company

108

GASEQ Chemical Equilibrium Software for Combustion

109

GHG

Greenhouse gases

$110 \quad \mathrm{H}_{2}$

Hydrogen

$111 \mathrm{HC}$

Hydrocarbon

112 IPCA

National consumer price index

113 LCA

Life Cycle Assessment

114 LFG

Liquified Petroleum Gas

115 LHV

Lower heating value

116 LNG

Liquid Natural Gas

117 MSR

Methane Steam Reforming

$118 \quad$ NG

Natural Gas

119 Nox

Nitrogen Oxide

120 ON

Octane Number

$121 \quad \mathrm{PM}$

Unburnt Hydrocarbon

122 PNPB

Program for production and use of biodiesel

123

SELIC

Special Custody Settlement System 
124 SFM Single Fuel Mode

125 TTW Tank-to-Wheel emission in $\mathrm{gCO} 2 \mathrm{eq} / \mathrm{km}$

126 UNFCCC United Nations Climate Change

127 WE Wind Energy

$128 \mathrm{Z} \quad$ Fuel proportion

129

130

131 GREEK CHARACTERS

132

$133 \varepsilon \quad$ Ecological energy efficiency

$134 \quad \Pi_{G W} \quad$ Global warming indicator

$135 \Pi_{H T} \quad$ Human toxicity indicator

$136 \Pi \quad$ Pollution indicator

$137 \Phi \quad$ Stoichiometric factor

138

139

140

141

142

143

144

145

146

147 


\section{INTRODUCTION}

151

152

153

Energy source formed thousands of years ago, the fossil fuels even nowadays are still widely accepted and used. As a primary source of energy, they are unsustainable, with imminent scarcity and contribution to environmental pollution. Since the industrial revolution breakthrough, especially in developing countries, energy demand grows significantly entailing chain reactions such as health concerns, environmental negative effects and high relative costs noticeable between government - citizen relationship (NADALETTI et al., 2015). Even with the adoption of different energy development models, focused on biomass use such as ProÁlcool (1975) and national program for production and use of biodiesel called PNPB, the contribution value of fossil fuels in the Brazilian energy matrix is still noteworthy.(NADALETTI et al., 2015) . Therefore, actions to favour the use of biofuels in transport sector, generates an opportunity for research.

In Brazil, the internal supply of energy reached 287.6Mtoe, recording a drop of $2.2 \%$ compared to the previous year, partly due to the sugarcane biomass and biodiesel offer increase and the non-renewable sources retraction supply, resulting from an atypical year of the coronavirus pandemic advent, both contributing to a renewable level of $48.4 \%$, higher than last year's with $46.1 \%$ (EPE, 2021).

According to BEN 2021, the transport sector was one of the most impacted by the COVID-19 pandemic, with its consumption having decreased by 5.5 million ton. Practically all fuels used suffered a decrease compared to 2019. Unlike light vehicles, which suffered with restrictive measures due to social distance, cargo transport was less affected by the pandemic since this mode it is essential for the supply of most brazilian cities. As a result, the brazilian transport sector presented an energy matrix composed of $25 \%$ of renewable sources in 2020 , maintaining the same level as the previous year and representing around $31.2 \%$ of total energy consumption, just behind the industrial sector, which owns of $32.1 \%$ (EPE, 2021).

Conventionally slow to change, the energy sector has experienced unprecedented dynamism in recent years, in large part due to the advent of renewables, even with limited 
employability at global scale. With the emergence of COVID-19 pandemic, renewables revealed significant resilience. In addition, the role in decarbonizing economies and the potential to create jobs by supporting economic recovery got them out of the supporting role to take the lead role (IRENA, 2021).

The 2030 Agenda consider sustainable transport techniques, as well as other associated energy methods and policies, would create a powerful economic foundation for all countries (SOLAYMANI; SHARAFI, 2021). In this regard, governments have a vital role to play in improving energy transition and limiting the global temperature increase to $1.5^{\circ} \mathrm{C}$. Policy priorities such as climate change, energy security, energy access and air pollution can place energy transition at high level of implementation (IRENA, 2021).

Biofuels have been successfully applied worldwide, in electricity production, transport or agricultural mechanization, being appointed for developing and industrialized countries (SIDIBÉ et al., 2010) .It can be generated in gas, solid and liquid form. (RODINOVA et al, 2017). Among the existing options, for specific applications like long distance driving or heavy-duty transport, biogas, biodiesel and hydrogen have great features. (WONG et al., 2015)

Due to low cetane number, gaseous fuels can be applied trough Dual Fuel technology, where de engine system operates on both liquid and gaseous fuels simultaneously. In diesel engines, the air temperature is more than $553 \mathrm{~K}$ close to the moment of diesel injection (ALOUCHEK et al., 2017). However, in dual fuel mode, there is a need to use liquid fuel is to attain the temperature at the end of the compression stroke in a Compression Ignition engine. The self-ignition temperature of gaseous fuel is lower and the temperature raise up to about $1087 \mathrm{~K}$ is mandatory (ALOUCHEK et al., 2017). Once, a liquid fuel with high Cetane number is fired in the air- gas fuel mixture at the end of compression stroke, initiates the ignition process of the gaseous fuel and the liquid fuel, known as the pilot fuel, acts as a source of ignition. The gaseous fuel is called the primary fuel on which the engine largely runs. Furthermore, it has been observed that the dual fuel engine requires a shortened combustion duration when compared to diesel conventional mode (ALOUCHEK et al., 2017).

The other benefits resulting from dual fuel mode engines employment includes: easier fallback to pure diesel mode in case of shortage of inducted gaseous fuels; no 
211 modification of the engine combustion chamber, substantial reductions of smoke and

212 NOx emissions, engine efficiency maintenance and versatility on fuel supply types like 213 hydrogen, biodiesel, Liquefied petroleum gas, methane, natural gas, producer gas, syngas and biogas,.(BORA; SAHA, 2016; SARKAR; SAHA, 2020)

In other hand, given the distinct attributes of two different fuels having dissimilar phases, the Dual Fuel Mode engine performance deteriorates considerably as compared with the engine's operation in pure diesel mode. The important methods suggested (Karim 1980) are control and quality of pilot fuels, modulating the inducted gaseous fuel in terms of gglobal, and intake charge preheating.(SARKAR; SAHA, 2020)

Many researchers from different perspectives are still investigating Dual Fuel compression ignition engine effects. DEHERI et al. (2020) centers on the application of biogas and hydrogen as alternative fuel in CI engine, noticing optimized performance and low emission characteristics. KHAYUM; ANBARASU; MURUGAN (2020) conducted in the DFM engine experiments to assess the performance, emission and combustion parameters, operating to run on three different mass flow rates of biogas, three different injection timings, and three different nozzle opening pressures. KHATRI; KHATRI (2020) through experimental results exposed the improvement of dual fuel mode performance with hydrogen-biogas-diesel fuel and emissions reduction. VERMA et al. (2020) investigates the usage of EGR and establish that it could improve the utilization of hydrogen in dual fuel engine, especially at the high loads. ROSHA et al. (2022) investigated hydrogen-enriched biogas and diesel in a DFM mode at variable compression ratios, noticing that in higher compression ratio improves the engine performance to a great extent, along with emissions reduction.

When it comes to the best of the authors' knowledge from scientific publication, literature efforts are directed to bioenergy research trends and prospects, themes like life cycle assessment, biomass conversion technologies, patent analysis and global energy use takes place. Due to the lacking scenario, there is a potential growth of studies regarding experimental studies of dual fuel mode fueled with liquid-gaseous application on CIE, such as energy efficiency, energy-ecological efficiency and economic estimative applied specifically to heavy load segment. 
considering different technologies. The cost of converting a truck engine to a dual-fuel system is expected to be minor when compared to the cost of the vehicle itself and the fuel consumed along the time, there is only the need to modify the fuel injection system and add tanks to store gaseous fuel in the truck. The annual maintenance fees are assumed to be the same for diesel conventional engine and dual fuel engine. Is even pertinent to anticipate fewer maintenance costs for the converted trucks, due to preliminary internal studies showing diesel particulate filter being less activated frequently under dual-fuel system. Since the conversion technique of a conventional vehicle to a dual fuel one is minimal, it does not require any additional maintenance actions over the lifetime period. While dual-fuel heavy duty trucks are currently under development by several major truck manufacturers, further research and development efforts are needed for these vehicles to become commercially available, consequently a solution that can be implemented as soon.(EL HANNACH et al., 2019)

Energy efficiency simply means using less energy to perform the same task, therefore, eliminating energy waste. It brings a range of benefits like reducing greenhouse gas emissions, reducing demand for energy imports, and lowering costs on a household and economy-wide level. Renewable energy technologies also assist to accomplish these purposes, introducing cheapest and often immediate ways to reduce the use of fossil fuels. In case of transport sector, more energy efficient vehicles require less fuel to cover a given distance. This generates fewer emissions and makes them significantly less expensive to operate, especially on the truck transportation segment.(RIMKUS; STRAVINSKAS; MATIJOŠIUS, 2020)

Based on above literature review, our research focuses on the evaluating of the possibility to replace the compression ignition engine powered only by conventional diesel to dual fuel compression ignition engine fueled by the proportions of soybean biodiesel and sugarcane biogas or soybean biodiesel and hydrogen produced through electrolysis with photovoltaic energy, electrolysis with wind energy, methane steam reforming without CCUS and biomass gasification as the solution to achieve the highest profitability from the alternatives fuels used and, at the same time, produce the minimum environmental impact. The present study is projected to fill this gap in the literature. This extensive investigation over dual fuel operation modes allied with waste energy valorization can be a potential solution to heavy road freight transport, fortifying decision-making sustainable and environmentally friendly technologies. The contribution 
of the paper is fourfold as we simultaneously obtain technology, environmental, economic and social contributions. Seen by technology contribution perspective the duel fuel technology does not involve any major engine modification only a pre-mixer is attached on the inlet manifold and the use of liquid fuel allied with gaseous fuel contributes to engine efficiency and fuel economy. Lower emissions and less harmful pollutants in the exhaust gas helps to reduce the percentage of greenhouse gases and prevents global warming, proving to be a great ally in the environmental context. Despite the additional cost when compared to the conventional diesel engine, the dual fuel system has an excellent cost-benefit ratio when applied to cargo vehicles due to the extensive useful lifetime on average of 20 years, allowing the investment to be easily diluted over the years. Lastly, Brazil has a great agricultural power and global interest is rising in green hydrogen as one of the solutions for an energy transition toward zero or net-zero emissions. which makes the dual fuel engine when powered by biofuels a potential alternative that can be socially accepted and able to promote new working fields

\section{METHODOLOGY}

The truck model delivery 6.160 Volkswagen was designated to estimate impacts on costs, health and environment through analysis of energy-ecological efficiency and cost estimative, aiming to replace the compression ignition engine fueled only with conventional diesel to dual-fuel compression ignition engine fueled with soybean biodiesel and sugarcane biogas or soybean biodiesel and Hydrogen produced through electrolysis with photovoltaic energy, electrolysis with wind energy, methane steam reforming without CCUS and biomass gasification. In addition, the mass flow for biodiesel/biogas and biodiesel/hydrogen for dual-fuel operation mode will be calculated. Therefore, this item divided into sections: Section 2.1 describes the operating modes of delivery 6.160 Volkswagen; Section 2.2 estimates mass flow rate of biodiesel, biogas and hydrogen for compression ignition engine; Section 2.3 shows the simulation of diesel, biodiesel, biogas and hydrogen combustion on GASEQ software; Section 2.4 demonstrates the estimation of the human toxicity and global warming indicator and calculation of the energy-ecological efficiency of the compression ignition engine; 2.5 estimates the life cycle costing to implement the dual fuel mode system. 


\subsection{Compression ignition engine operating modes}

309

The truck model delivery 6.160 Volkswagen has three operate engine mode:

311 Single compression ignition engine fueled with Diesel, Dual-fuel compression ignition

312

The single compression ignition engine, or in other words, the diesel engine is a machine that transforms thermal energy into mechanic energy obtained from fuel combustion inside the engine cylinder. having principles of intake, compression, combustion, and discharge. Unlike otto engines, the Diesel engine uses higher compression, igniting the fuel instead of using spark plug. Figure 1 describes the Single Fuel compression ignition engine operation mode

Single Fuel Compression ignition engine Dinamic

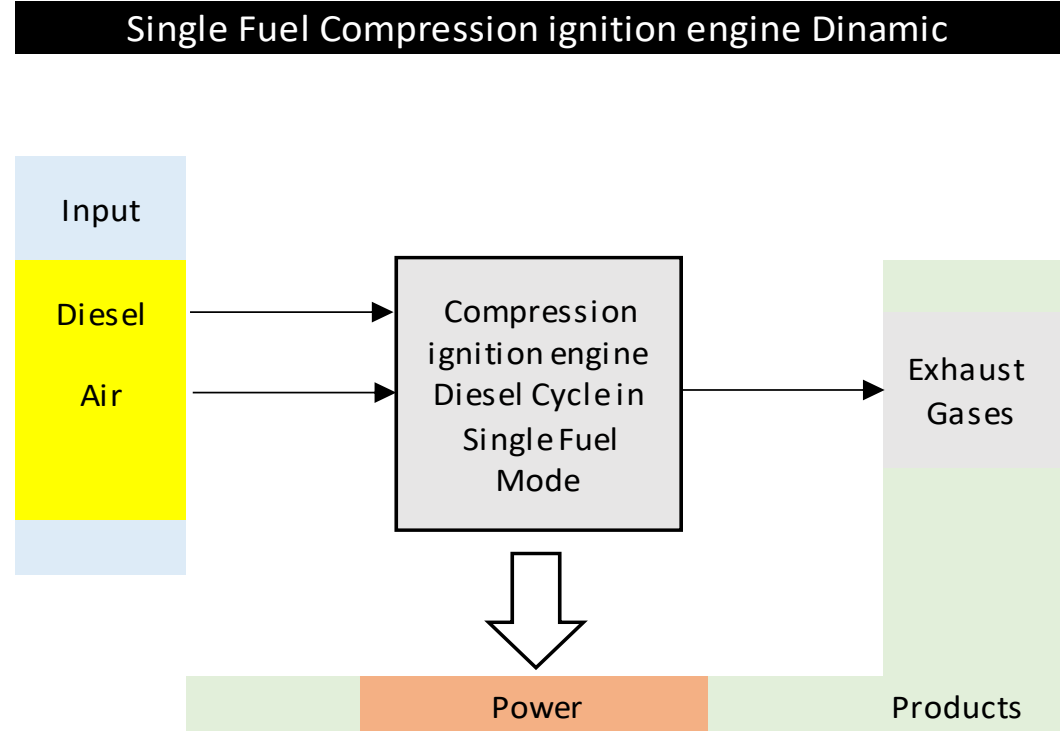

Figure 1: Single Fuel compression ignition engine operation mode Source: Self-elaboration

The operation begins with the ignition of the engine. Due to the compression of the air, the temperature in the chamber rises, with combustion occurring in such a way 
that it reaches the point of self-inflammation of the fuel. The diesel when introduced into the chamber by means of an injector, meets heated air suffering from combustion and consequently expelling emitting gases. The accelerator will regulate the amount of fuel supplied by the pump and, consequently, the power that the engine will generate. with a mixture of liquid fuel and gas fuel, giving preference to the gas fuel to take advantage of the economic and environmental benefits. In this study the proportions biodiesel-biogas and biodiesel-hydrogen will be considered. mode under biodiesel+biogas and biodiesel+hydrogen mixtures.

\section{Dual-Fuel Compression ignition engine Dinamic}

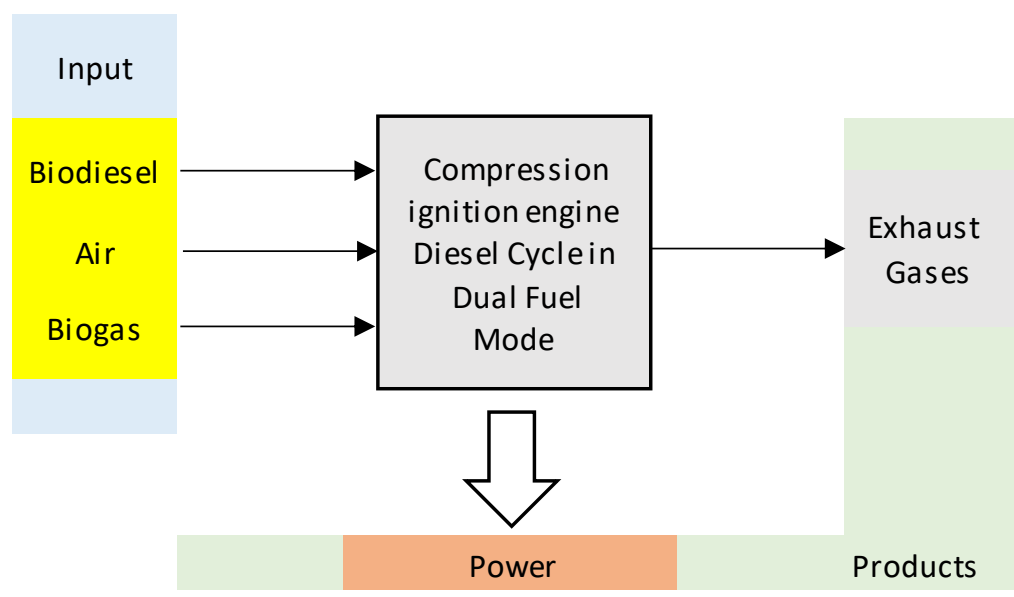

Figure 2: Dual-Fuel compression ignition engine operation mode 


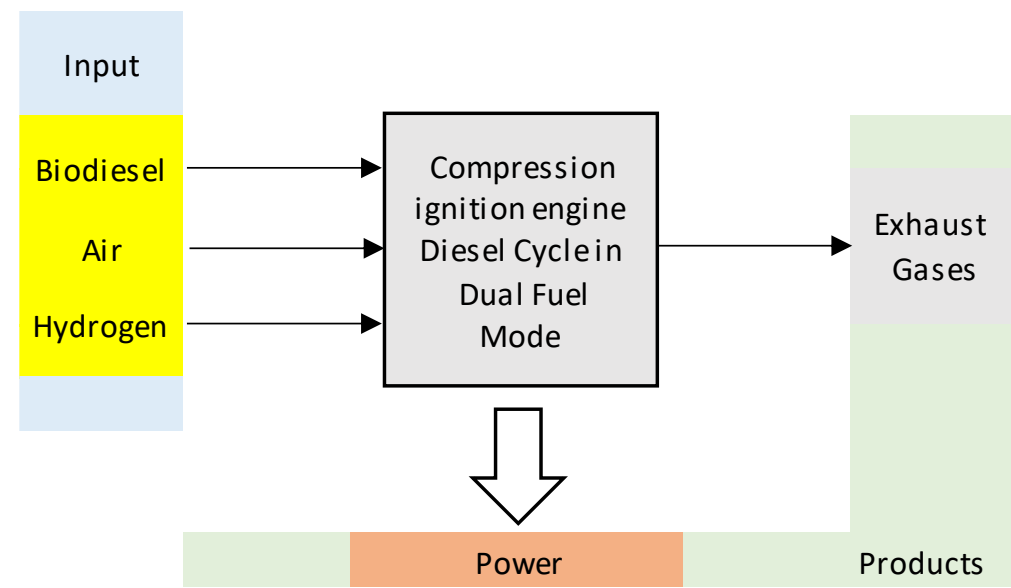

Figure 3: Dual-Fuel compression ignition engine operation mode

$$
\text { Source: Self-elaboration }
$$

In this case, the gas is mixed with air before the intake valve during the air intake period. After the compression phase, the gas air mixture is ignited by small amounts of liquid pilot fuel, which is pressurized and fed to the cylinder by a small common rail system. Combustion is fast, and after the working phase the exhaust gas valve open and the cylinder is empty from the exhaust gases. Lastly, the inlet air valve open when the exhaust gas valve close and the process starts again.

The vehicle chosen to perform the cost analysis was Delivery 6.160, a medium truck manufactured by Volkswagen, being the best seller in its category and widely used for urban and road freight. The Volkswagen Delivery is a heavy- load disguised as a pickup truck. It has a cabin, chassis, engine and truck gearbox. But, according to the Brazilian Traffic Code, it is a medium pickup truck. It is a Volkswagen vehicle that can be driven by ordinary drivers, with B license. The B license in Brazil allows to drive vehicles with up to eight passengers and that do not exceed $3.500 \mathrm{~kg}$, which is exactly the total gross weight approved by Delivery Express, in this way, the Delivery truck pays as car toll and has no traffic restrictions in cities or roads and in the eyes of the legislation it is like Hyundai HR. Brazilian labeling program estimates the Delivery Express energy consumption and efficiency as D in general classification out of a scale from A to E and B classification when compared to its own category.(INMETRO, 2020).Table 1 presents the truck specifications provided by Volkswagen: 


\begin{tabular}{|l|c|}
\hline \multicolumn{2}{|c|}{$\begin{array}{l}\text { Truck } \\
\text { specifications }\end{array}$} \\
\hline \multicolumn{2}{|c|}{ Delivery Express } \\
\\
\multicolumn{1}{|c|}{} \\
\hline Categorie & Medium Truck \\
\hline Brand & Volkswagen \\
\hline Model & Delivery 6.160 \\
\hline Power (Kw) & 110 \\
\hline Autonomy (km) & C40 (City) / (Road) \\
\hline Income (km/l) & 5.5 (City)/ 8 (Road) \\
\hline Engine & Cummins ISF 2.8 Turbocompressor - 4 \\
\hline Tank Fuel (L) & Cylinder \\
\hline
\end{tabular}

3.2 Energetic Analysis. Mass flow rate of biodiesel, biogas and hydrogen in dual-fuel mode

When the engine is powered by two fuels, it is necessary to consider the proportion can be calculated as demonstrated in Eq. (1) and Eq. (2) respectively. 

power, in $\mathrm{kW} ; \mathrm{m}$ is the biogas and hydrogen flow required, in $\mathrm{kg} / \mathrm{s}$; $\mathrm{LHV}$ is the low heating value of biogas and hydrogen, in $\mathrm{kJ} / \mathrm{kg}$; $\mathrm{z}$ represents the proportion of biodiesel replaced by biogas or hydrogen, whose value varies between $0 \%-100 \%$, with $\mathrm{z}=0 \%$ normal operation (single fuel mode) and $\mathrm{z}>0 \%$ dual-fuel mode operation with gaseous fuel (primary fuel) and liquid fuel (pilot fuel). According to (BORA; SAHA, 2016) the BTE dual fuel is $19.54 \%$. The biodiesel mass flow rate, in $\mathrm{kg} / \mathrm{s}$, of the DFM can be obtained from Eq. (3).

$m_{\text {biodiesel }}=\frac{\frac{p}{\text { BTE dual-fuel }}-\left(m_{\text {gaseous fuel }} \times L H V_{\text {gaseous fuel }}\right)}{L H V_{\text {biodiesel }}}$

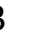

When the motor is powered by a single fuel, or in other words, running in the combustion ignition engine mode fed only by conventional diesel, the mass flow rate in $\mathrm{kg} / \mathrm{s}$ can be obtained through Eq. (4).

$B T E_{\text {diesel }}=\frac{B P}{m_{\text {diesel }} X L H V_{\text {diesel }}}$

\subsection{Combustion simulation on GASEQ}

GASEQ developed by Chris Morley and distributed free of charge, is the most interesting free combustion package find on the Internet for chemical equilibrium program. Several different types of problem can be solved, such as composition at a defined temperature and pressure; adiabatic temperature and composition at constant pressure; composition at a defined temperature and at constant volume; adiabatic temperature and composition at constant volume; adiabatic compression and expansion; equilibrium constant calculations and shock calculations.

It can create combustion equilibrium simulations by setting the desired parameters and performing complex calculations involving ideal gases. it's possible to automatically increment any of the problem parameters, save the results in a spreadsheet, define mixtures and use as a single species, calculate equilibrium while specifying concentrations of unreactive species, handle "super-equilibrium" radical concentrations, 
enter and display species concentrations in mass as well as molar units, calculate viscosities and thermal conductivities of mixtures of gases and use multiple thermodynamic database files in a standard NASA polynomial format.

Making use of GASEQ software it was possible to evaluate the combustion reaction of Diesel (Eq 5), biodiesel (Eq 6), Hydrogen (Eq 7) and biogas with 60\% $\mathrm{CH} 4$ and 40\% CO2 (SARKAR; SAHA, 2018) (Eq 8). The combustion simulation was promoted in separate analysis. Diesel engines always operate with a significant excess of air (lean burn, $\alpha>1$ ). Diesel engines operate with $12 \leqslant A / F$ ratio $\leqslant 70$; therefore, the excess of air for diesel and biodiesel fuel was considered to be $100 \%$ and excess air for biogas and hydrogen considered to be 40\%. (CORONADO et al., 2009a) .

Diesel is a fuel formed mainly by carbon and hydrogen. The equation $\left(\mathrm{C}_{16} \mathrm{H}_{36}\right)$ was rewritten as $4 C_{4} H_{9}$ to run on the GASEQ software and promote evaluation.

$4 \mathrm{C}_{4} \mathrm{H}_{9}+50 \mathrm{O}_{2}+188,65 \mathrm{~N}_{2} \rightarrow 16 \mathrm{CO}_{2}+18 \mathrm{H}_{2} \mathrm{O}+25 \mathrm{O}_{2}+188,65 \mathrm{~N}_{2}$

The average fatty acid distribution for soybean biodiesel compounds products as it shown in Table 2. Biodiesel already has as its initial advantage the very small or zero presence of sulfur, having no combustion emission products containing this gas. The simplified equation was adopted:

$$
\mathrm{C}_{18} \mathrm{H}_{32} \mathrm{O}_{2}+50 \mathrm{O}_{2}+188 \mathrm{~N}_{2} \rightarrow 18 \mathrm{CO}_{2}+16 \mathrm{H}_{2} \mathrm{O}+25 \mathrm{O}_{2}+188 \mathrm{~N}_{2}
$$

Table 2: Typical soybean oil methyl ester

\begin{tabular}{lccc}
\hline \multicolumn{1}{c}{ Fatty acid } & Weight(\%) & Mol.Wt (g) & Formula \\
\hline Palmitic (A) & 12 & 270.46 & $\mathrm{C} 15 \mathrm{H} 31 \mathrm{CO} 2 \mathrm{CH} 3$ \\
Stearic (B) & 5 & 298.52 & $\mathrm{C} 17 \mathrm{H} 35 \mathrm{CO} 2 \mathrm{CH} 3$ \\
Oleic (C) & 25 & 296.5 & $\mathrm{C} 17 \mathrm{H} 33 \mathrm{CO} 2 \mathrm{CH} 3$ \\
Linoleic (D) & 52 & 294.48 & $\mathrm{CH} 3(\mathrm{CH} 2) 4 \mathrm{CH}=\mathrm{CHCH} 2 \mathrm{CH}=\mathrm{CH}(\mathrm{CH} 2) 7 \mathrm{CO} 2 \mathrm{CH} 3$ \\
Linolenic (E) & 6 & 292.46 & $\mathrm{CH} 3(\mathrm{CH} 2 \mathrm{CH}=\mathrm{CH}) 3(\mathrm{CH} 2) 7 \mathrm{CO} 2 \mathrm{CH} 3$ \\
\hline
\end{tabular}

Source: adapted from (CORONADO et al., 2009a)

In case of Biogas, the composition has a mixture of gases where methane and carbon dioxide are in greater proportions and the other gases present are considered in the forty percent of carbon dioxide. After the purification process, biogas has a very low or zero sulfur values. 
442

443

Hydrogen has a wide range of flammability when compared to other fuels. As a

444 result, it can be burned in a compression ignition engine in a wide variety of fuel-air 445 proportions.

446

$\mathrm{H}_{2}+0.7\left(\mathrm{O}_{2}+3.773 \mathrm{~N}_{2}\right) \rightarrow \mathrm{H}_{2} \mathrm{O}+2.63 \mathrm{~N}_{2}$

447

448

3.4 Energy-ecological efficiency

449

450

Proposed by (CÂRDU; BAICA, 2001) Eq (9), the method energy-ecological 451 efficiency $(\mathcal{E})$ considers the potential of air pollution and the efficacy concerning to convert fuel into energy and estimate human toxicity and the global warming indicators for SFM Eq.(10) and Eq. (11), Eq. (12-13) for DFM.(CARNEIRO; GOMES, 2019)

454

455

$\varepsilon=\left[c \frac{n}{n+\Pi} \ln (K \pm \Pi]^{\mathrm{N}}\right.$

456

457

$\Pi_{G W}=\frac{f_{c o 2 e q}}{L H V_{f u e l}}$

458

$459 \quad \Pi_{H T}=\frac{f_{1,4 \text { DCBeq }}}{L H V_{\text {fuel }}}$

460

$461 \quad \Pi_{G W}=\frac{f_{\text {co } 2 \text { eq }}}{Z * L H V_{\text {Gaseous fuel }}+(100-z) * L H V_{\text {Lquid Fuel }}}$

462

463

$\Pi_{H T}=\frac{f_{1.4 D C B e q}}{Z * L H V_{\text {Gaseous fuel }}+(100-z) * L H V_{\text {Lquid Fuel }}}$ 
466 in $k g_{\text {eq.pollutant }} / M J_{\text {fuel }}$; and $\Pi_{H T}$ considers the emissions that contribute to human 467 toxicity, expressed in $\mathrm{kg} 1.4 \mathrm{DCBeq} / \mathrm{kgfuel}$, being 1.4-dichlorobenzene the substance 468 used to calculate the level of human toxicity (CARNEIRO; GOMES, 2019). The 469 equivalent carbon dioxide emission factor $\left(f_{c o 2 ~ e q}\right)$ and the equivalent 1.4470 dicholobenzene emission factor $\left(f_{1.4 \mathrm{DCB} e q}\right)$ for single fuel mode is determined through 471 the Eq. (14) and (15).

472

473

$f_{\mathrm{CO} 2 \mathrm{eq}}=f_{\mathrm{CO} 2}+28 f_{\mathrm{CH} 4}+265 f_{\mathrm{N} 20}$

474

475

$f_{1,4 D C B e q}=4.54 f_{\text {SO2 }}+56.71 f_{\text {NOX }}+38.75 f_{M P}$

476

477

In case of the compression ignition engine operates in dual fuel mode, the value for $f_{D F C o 2 ~ e q}$ and $f_{1,4 D C B e q}$ considers the proportion of liquid fuel replaced by gaseous fuel and can be determined by Eq. (16) and Eq (17) respectively:

480

481

$f_{\text {DFco2 eq }}=Z * f_{\text {Gaseous Fuel co2 eq }}+(100-Z) * f_{\text {Liquid Fuel co2 eq }}$

482

483

$f_{D F 1,4 D C B e q}=Z * f_{\text {Gaseous Fuel 1,4DCBeq }}+(100-Z) * f_{\text {Liquid Fuel 1,4DCBeq }}$

484

485

The specie emission factor $\left(f_{\text {specie }}\right)$ represents the emission factor of each species 486 rising from the combustion of the air-fuel mixture, in $k g_{\text {specie }} / M J_{\text {fuel }}$, determined by 487 Eq. (18):

488

489

$f_{\text {specie }}=\frac{\left(n_{\text {specie }} \times W_{\text {specie }}\right)}{\left(n_{\text {fuel }} \times W_{\text {fuel }}\right)}$ 

through Eq. (19), stated in $k g_{\text {eq pollutant }} / M_{\text {fuel }}$ for both operation modes, single fuel mode and dual fuel mode:

494

495

$\Pi=0.742 \Pi_{H T}+0.258 \Pi_{G W}$

496

497

498

Ultimately, the energy-ecological efficiency can be acquired through Eq. (20), applying c, K and n constant values considered by (CARNEIRO; GOMES, 2019)

499

500

$\varepsilon=\left[2.01 \frac{n}{n+\Pi} \ln (1.645 \pm \Pi] 1.7\right.$

501

502

3.5 Environmental Life Cycle Cost

503

504

Combining the aforementioned equations and the parameters illustrates in Table 505

3 , it becomes possible to calculate de liquid and gaseous fuels flows required to power a 506 diesel engine operating in single and dual-fuel mode of a heavy-duty vehicle and later 507 estimate the autonomy archived.

508

Table 3: Parameters adopted in fuel consumption calculations

\begin{tabular}{|c|c|c|c|}
\hline Parameter & Value & Unit & Reference \\
\hline $\mathrm{BP}$ & 110 & $\mathrm{~kW}$ & $\begin{array}{l}\text { Medium Truck, Cummins ISF } 2.8 \text { Turbo } \\
\text { compressor Motor (VWCO, 2020) }\end{array}$ \\
\hline $\begin{array}{l}\text { LHV } \\
\text { Hydrogen }\end{array}$ & 120.0 & $\mathrm{Mj} / \mathrm{kg}$ & $\begin{array}{l}\text { (KORAKIANITIS; NAMASIVAYAM; } \\
\text { CROOKES, 2011) }\end{array}$ \\
\hline $\begin{array}{l}\text { LHV } \\
\text { Diesel }\end{array}$ & 42.1 & $\mathrm{Mj} / \mathrm{kg}$ & (SARKAR; SAHA, 2020) \\
\hline LHV BG & 17.65 & $\mathrm{MJ} / \mathrm{kg}$ & (ALOUCHEK et al., 2017) \\
\hline LHV BD & 34.04 & $\mathrm{MJ} / \mathrm{kg}$ & (MOURAD; WALTER, 2011) \\
\hline BTE CIE & 27.76 & $\%$ & (BORA; SAHA, 2016) \\
\hline BTE DFM & 19.54 & $\%$ & (BORA; SAHA, 2016) \\
\hline $\mathrm{Z}$ biogas & 70 & $\%$ & (BORA et al., 2014) \\
\hline $\begin{array}{l}\text { Z } \\
\text { Hydrogen }\end{array}$ & 70 & $\%$ & (HOSSEINI; AHMADI, 2017) \\
\hline
\end{tabular}


To execute the environmental life cycle cost of a heavy duty vehicle operating in single fuel mode (diesel fuel) and dual fuel mode powered by liquid-gaseous proportions 514 (soybean biodiesel- sugarcane biogas, soybean biodiesel-hydrogen produced through electrolysis with photovoltaic energy, electrolysis with wind energy, methane steam reforming without CCUS and biomass gasification their lifetime was considered, taking into account the Capital cost $C_{C A P}$, Operational cost $C_{O P}$, reposition and technology cost

$518 C_{R E P}$. With the same parameters it is possible to obtain the annual cost for the heavy duty 519 vehicle life cycle (Life Cicle Cost $-\mathrm{C}_{\mathrm{LC}}$ ) in $\mathrm{R} \$ / \mathrm{km}$, as follows the adapted equations (21)

$$
C_{C L C}=C_{C A P}+\left(C_{O P}+C_{R E P}\right) X\left(1+d_{\text {rate }}\right)^{-J}
$$

$$
C_{\mathrm{CO} 2}=E_{\mathrm{CO} 2} X P_{\mathrm{CO} 2}
$$

$$
E_{\mathrm{CO} 2}=m_{\text {fuel }} X F_{\text {fuel }}
$$

530

Where, $C_{C a p}=$ Vehicle acquisition cost in $\mathrm{R} \$ / \mathrm{km}, C_{O P}=$ vehicle operational cost in $\mathrm{R} \$ / \mathrm{km}, C_{\text {rep }}=$ reposition and technology cost in $\mathrm{R} \$ / \mathrm{km}, d_{\text {rate }}=$ market rate fees in $\%$ per year, $\mathrm{j}=$ vehicle lifetime in years, $\mathrm{Cm}=$ Maintenance cost in $\mathrm{R} \$ / \mathrm{km}, C_{n}=$ cost of the energy supplied by fuel in $\mathrm{R} \$, \mathrm{C}_{\mathrm{CO} 2}=\mathrm{CO}_{2}$ cost in $\mathrm{R} \$ / \mathrm{km}, E_{\mathrm{CO}_{2}}=\mathrm{CO}_{2}$ emission $(\mathrm{kg}$ de $\mathrm{CO} 2 / \mathrm{h}), \mathrm{PCO}_{2}=\mathrm{CO}_{2}$ market credit price in $\mathrm{R} \$ / \mathrm{kg}$ de $\mathrm{CO}_{2}, m_{\text {fuel }}=$ Fuel mass flow in $\mathrm{kg} / \mathrm{h}$ and $F_{\text {fuel }}=$ Fuel emission factor in $\mathrm{kg}$ of $\mathrm{CO}_{2} / \mathrm{kg}$ of fuel

\section{RESULTS AND DISCUSSION}

In this study, the mass flow rate of biodiesel, biogas and hydrogen were calculated, 
541 ascertained. The emission factors were determined to calculate the energy-ecological

542 efficiency and the TTW emissions of the single fuel compression ignition engine powered

543 with Diesel and Dual-Fuel compression ignition engine powered by proportions of

544 Biodiesel-Biogas and Biodiesel-Hydrogen.

$545 \quad 4.1$ Diesel, Biodiesel, Hydrogen and Biogas mass flow in dual-fuel mode results

546

547

548

549

550

551

552

553

554

555

556

557

558

559

560

561

562

The biodiesel, Hydrogen and biogas mass flows in the dual fuel mode were determined, considering $\mathrm{z}$ value equal to $70 \%$. The Eq. (1) was applied to calculate the Biogas mass flow adopting 19.54\% BTE dual fuel by (BORA; SAHA, 2016).Then, the hydrogen mass flow was measured trough Eq. (2). Lastly, the biodiesel and Diesel mass flow were measured trough Eq (3) and Eq. (4). The values found for biodiesel-hydrogen and biodiesel-biogas mass flows were $6.45 \mathrm{~kg} / \mathrm{h}$ and $26.94 \mathrm{~kg} / \mathrm{h}$ respectively. The conventional Diesel mass flow were $33.88 \mathrm{~kg} / \mathrm{h}$ as shown in the graphic 1 .

Graphic 1. Mass Flow rate from different fuels

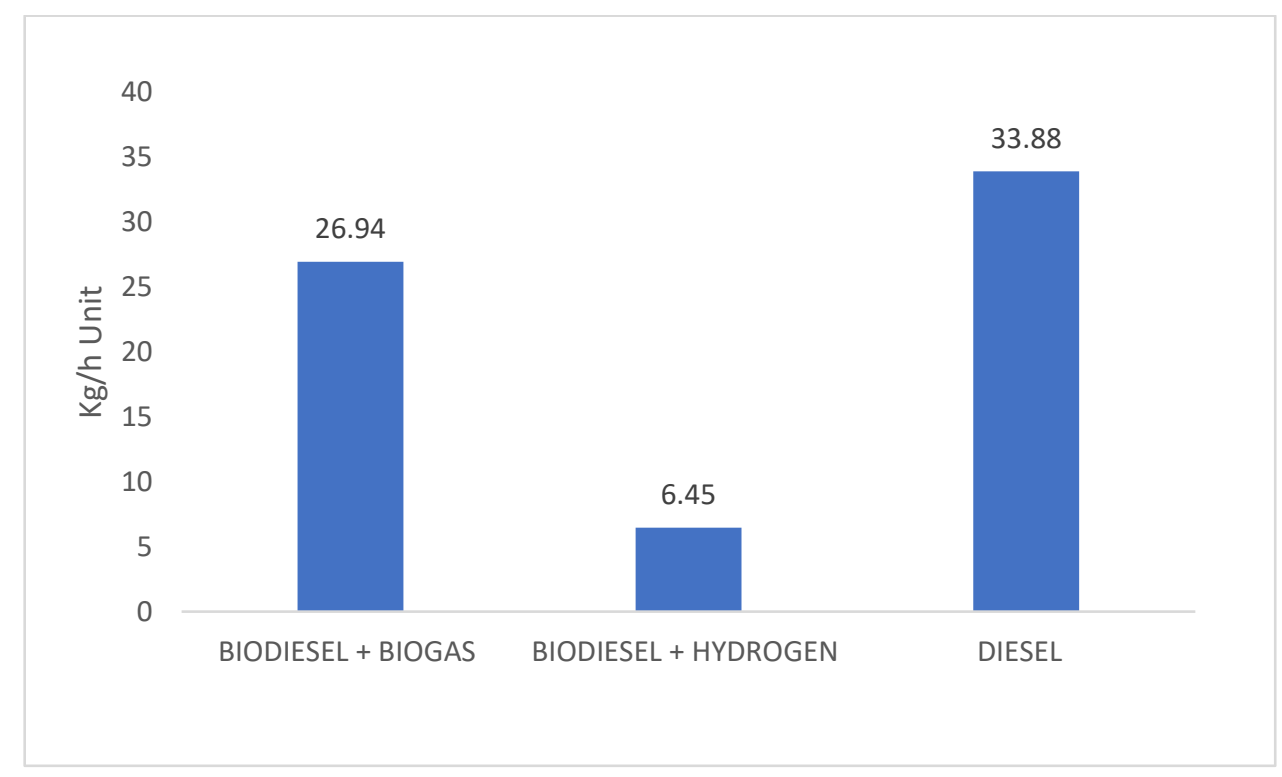

Source: Self-elaboration

Mas flow rate is a way to quantify the use of chemical energy from the fuel by the engine, being able to compare different operating points on different engines occurs by calculating the thermal yield. It can be expressed in terms of speed the fuel takes to archive the Maximo point and fulfill the engine's necessity to complete combustion phase. The combination of biodiesel and hydrogen, having the MFR of $6.45 \mathrm{~kg} / \mathrm{h}$ is the 
563 faster in terms to archive the ignition timing. In other hand, with MFR of $26.94 \mathrm{~kg} / \mathrm{h}$, the

564

565

566

567

568

569

570

571

572

573

574

575

576

577

578

579

580

581

582

\subsection{GASEQ simulation and indicators}

With the GASEQ results assistance, it becomes accessible to evaluate the combustion reaction with the values of $\mathrm{CO}_{2}, \mathrm{~N}_{2} \mathrm{O}, \mathrm{SO}_{2}, \mathrm{NO}_{\mathrm{X}}$ and MP used to calculate emission factors and pollution indicators in the scenarios of compression ignition engine fed only by diesel and in dual fuel mode fed by biodiesel-biogas or biodiesel-hydrogen proportions. The stoichiometric relation with air and Biodiesel, Biogas, Hydrogen and Diesel were analyzed separately trough eq.(5) eq.(6) eq.(7) eq.(8), being used to evaluate their respective indicators of global warming and human toxicity.

The following tables 4-7 indicates the reagent species, products from each simulation and their respective emission factors, related to global warming indicators and human toxicity, calculated trough eq. (11) and eq. (12)

Table 4: Reactants and products, and specie emission factors of the biodiesel-air mixture combustion.

\begin{tabular}{cccc}
\cline { 1 - 2 } Reagents & No. Moles & Molecular Weight & \\
$\mathrm{C} 18 \mathrm{H} 32 \mathrm{O} 2$ & 1 & 280 & \\
$\mathrm{O} 2$ & 50 & 32 & \\
$\mathrm{~N} 2$ & 188 & 28 & \\
\cline { 1 - 3 } Products & No. Moles & Molecular Weight & F species \\
$\mathrm{CO}_{2}$ & 18 & 44 & 2,82857 \\
$\mathrm{CH}_{4}$ & 0.00 & 16 & $2,8384 \mathrm{E}-27$ \\
$\mathrm{~N}_{2} \mathrm{O}$ & 0.00 & 44 & 0 \\
$\mathrm{SO}_{2}$ & 0.00 & 64 & 0 \\
$\mathrm{NO}_{\mathrm{x}}$ & 0.02 & 30 & 0,32748 \\
$\mathrm{MP}$ & 0.00 & 12 & 0 \\
\hline
\end{tabular}

Source: Adapted from GASEQ

Table 5. Reactants and products, and specie emission factors of the Hydrogen-air mixture 
combustion.

\begin{tabular}{|c|c|c|c|c|}
\hline & & & & \\
\hline & Reagents & No. Moles & Molecular Weight & \\
\hline & $\mathrm{H} 2$ & 1 & 1 & \\
\hline & $\mathrm{O}_{2}$ & 0,7 & 32 & \\
\hline & $\mathrm{N}_{2}$ & 2,6411 & 28 & \\
\hline & Products & No. Moles & Molecular Weight & F species \\
\hline & $\mathrm{CO}_{2}$ & 0 & 44 & 0 \\
\hline & $\mathrm{CH}_{4}$ & 0 & 16 & 0 \\
\hline & $\mathrm{N}_{2} \mathrm{O}$ & 0 & 44 & $7,30 \mathrm{E}-07$ \\
\hline & $\mathrm{SO}_{2}$ & 0 & 64 & 0 \\
\hline & $\mathrm{NO}_{\mathrm{x}}$ & 0.02 & 30 & 0,4662 \\
\hline 585 & MP & 0 & 12 & 0 \\
\hline 586 & & Source: $A$ & from GASEQ & \\
\hline
\end{tabular}

587

Table 6: Reactants and products, and specie emission factors of the biogas-air mixture combustion

\begin{tabular}{cccc}
\cline { 1 - 2 } Reagents & No. Moles & $\begin{array}{c}\text { Molecular } \\
\text { Weight }\end{array}$ \\
$\mathrm{CH}_{4}$ & 0,6 & 16 & \\
$\mathrm{CO}_{2}$ & 0,4 & 44 & \\
$\mathrm{O}_{2}$ & 1.60 & 32 & \\
$\mathrm{~N}_{2}$ & 6.04 & 28 & F species \\
\hline Products & No. Moles & Molecular & Weight \\
$\mathrm{CO}_{2}$ & 1 & 44 & 1,61571 \\
$\mathrm{CH}_{4}$ & 0 & 16 & 22 \\
$\mathrm{~N}_{2} \mathrm{O}$ & 0 & 44 & $1,41 \mathrm{E}-01$ \\
$\mathrm{SO}_{2}$ & 0 & 64 & 0 \\
$\mathrm{NO}_{\mathrm{x}}$ & 0.02 & 30 & 0,019929 \\
$\mathrm{MP}$ & 0 & 12 & 0 \\
\hline \multicolumn{5}{c}{ Source: Adapted from GASEQ } \\
\end{tabular}


593

602

603

604

605

606

607

608

\begin{tabular}{cccc}
\hline Reagents & No. Moles & Molecular Weight & \\
$\mathrm{C}_{4} \mathrm{H}_{9}$ & 4 & 57 & \\
$\mathrm{O}_{2}$ & 50 & 32 & \\
$\mathrm{~N}_{2}$ & 188,65 & 28 & \\
\hline Products & No. Moles & Molecular Weight & F species \\
$\mathrm{CO}_{2}$ & 16 & 44 & 3,08772 \\
$\mathrm{CH}_{4}$ & 0 & 16 & $3,5480 \mathrm{E}-26$ \\
$\mathrm{~N}_{2} \mathrm{O}$ & 0 & 44 & 0 \\
$\mathrm{SO}_{2}$ & 0 & 64 & 0 \\
$\mathrm{NO}_{\mathrm{x}}$ & 0.02 & 30 & 0,32748 \\
$\mathrm{MP}$ & 0 & 12 & 0 \\
\hline
\end{tabular}

Source: Adapted from GASEQ

Table 8 presents the values of $f_{C O 2 \text { eq }}$ and the $f_{1,4 D C B e q}$ resulting from the combustion of diesel, biodiesel, biogas and hydrogen fuels in compression ignition engine operating in single fuel mode.

Table 8: Carbon dioxide and 1.4-Dichorobenzene equivalent factors of the fuels evaluated when compression ignition engine operates in single fuel mode

\begin{tabular}{|c|c|c|c|c|}
\hline Fuel & & $\mathrm{F}_{\mathrm{CO} 2 \mathrm{eq}}$ & & F 1.4 DCBeq \\
\hline Diesel & 3,0877 & $\mathrm{kgCO} 2 \mathrm{eq} / \mathrm{kg}$ Diesel & 18,5710 & kg 1.4 DCBeq/kg Diesel. \\
\hline Biodiesel & 2,8285 & $\mathrm{kgCO} 2$ eq/kg BD & 19,499 & $\mathrm{~kg} 1.4 \mathrm{DCBeq} / \mathrm{kg} \mathrm{BD}$ \\
\hline Hydrogen & 0,00019 & $\mathrm{kgCO} 2 \mathrm{eq} / \mathrm{kg} \mathrm{H} 2$ & 0,88192 & kg 1.4 DCBeq/kg H2 \\
\hline Biogas & 1,6157 & $\mathrm{kgCO} 2 \mathrm{eq} / \mathrm{kg} \mathrm{BG}$ & 1,1301 & $\mathrm{~kg} \mathrm{1.4} \mathrm{DCBeq/kg} \mathrm{BG}$ \\
\hline
\end{tabular}

Source: Self-elaboration

As can be seen, the highest value of Fco2 was found through Diesel fuel, due to the greater number of moles of $\mathrm{CO}_{2}$ resulting from its combustion, with insignificant values of $\mathrm{CH} 4$ and $\mathrm{CO}_{2}$. On the other hand, Biodiesel presented the highest value of $\mathrm{f} 1.4$ DCBeq due to the NOx emissions increase in 5\%. The stoichiometric ratio, temperature 
617

618

619

620

621

622

623

624

625

626

627

628

629

630

and type of fuel can contribute, thus it depends on how the fuel is injected, the reaction dynamics and engine operation. According to CORONADO et al. ( 2009) the increment is originated by the temperature increase in the tailpipe engine, which appears due to reduction of the delay ignition, and, as outcome, to the injection point advance.

Table 9 provides values of $f_{D F C o 2 ~ e q}$ and the $f_{D F 1,4 D C B e q}$ resulting from the compression ignition engine running in dual fuel mode according to eq (12) and eq (13).

Table 9. Carbon dioxide and 1.4-Dichorobenzene equivalent factors of the fuels evaluated when compression ignition engine operates in dual fuel mode.

\begin{tabular}{ccc}
\hline Dual Fuel & FCO2eq & F1.4 ADCBeq \\
\hline & & \\
\hline $\begin{array}{c}\text { Biodiesel+ } \\
\text { Biogas }\end{array}$ & 1,9795 & 6,6411 \\
\hline Biodiesel+H2 & 0,8487 & 24,3567 \\
\hline
\end{tabular}

Source: Self-elaboration

The proportions of Biodiesel and hydrogen presents the smallest amount of $\mathrm{Fco}_{2}$ among the two dual fuel scenarios but at the same time, has the biggest value when it comes to F1.4 $4_{\mathrm{ADCBeq}}$ emissions. This is due to hydrogen, responsible for $70 \%$ of the Dual Fuel mode. Hydrogen system has emissions close to zero $\mathrm{CO} 2$ but at the same time, it has a considerable proportion of NOx, which ends up influencing the $\mathrm{F}_{1.4 \mathrm{ADCBeq}}$ final calculation.

Energy ecological efficiency considerers the air pollution potential and the engine conversion effectiveness to energy. Between these parameters it is possible to estimate human toxicity and the global warming indicators. Once the equivalent values are found, the $\Pi_{G W}$ and $\Pi_{H T}$ for SFM and DFM were estimated through eq (10-13). The results can be seen in the graphic 2 . 
scenarios

632

633

634

635

636

637

638

639

640

641

642

643

644

645

646

647

648

649

650

651

The ecological efficiency concept depends on the environmental impact caused by $\mathrm{CO} 2, \mathrm{SO} 2, \mathrm{NOx}$ and particulate material (PM) emissions. The best scenario from the ecological standpoint is that which presents a minimum amount of $\mathrm{CO} 2$. Biodiesel + Biogas and Biodiesel + Hydrogen present equal values of II, however, in a closer analysis of the values of IIGW and IIHT it is possible to notice a significant decrease in emissions from the Biodiesel + Hydrogen scenario. The share of Hydrogen causes a decrease of soot and $\mathrm{CO}_{2}$ emissions, except for nitric oxide emissions.

\subsection{Energy-ecological efficiency in combustion ignition engine modes}

Diesel engines are the source of very fine particles ranging from 0.01 to $1 \mathrm{~mm}$. These particles are able to penetrate deep inside the lungs and cross the walls of the blood vessels causing major health issues. In contrast, gasoline engines produce 100 times less particles than diesel engines. (EL HANNACH et al., 2019)

There are several current regulations to limit the harmful emissions from diesel engines, especially heavy-duty vehicles. Ordinance IBAMA nº 85 from 1996 deal with the creation and adoption of an internal self-inspection program for correct fleet maintenance, regarding the black smoke emission, by a company that has its own cargo 
652

653

654

655

656

657

658

659

660

661

662

663

664

665

666

667

668

669

670

or passenger transport fleet powered by diesel oil. EURO 6 from 2015 obligates all road vehicles manufactured in European Union countries since year 2015 to comply limited levels of particulate emissions (4.5 mg/km) and Nox.( $80 \mathrm{mg} / \mathrm{km})$. Law 8.723/93, as part of the Brazilian National Environment Policy, determines engine and motor vehicle manufacturers and fuel manufacturers to fulfill necessary steps to reduce the levels of carbon monoxide, nitrogen oxide, hydrocarbons, alcohols, aldehydes, soot, particulate matter and other polluting compounds in vehicles sold in the country, within the limits set in the law and also respecting the deadlines established.

Technologies such as diesel particulate filters (DPF), exhaust gas recirculation (EGR), and selective catalytic reduction (SCR) have been introduced to new diesel vehicles. However, the commercial truck fleet industry will still be dominated by older vehicles over the next two decades.(EL HANNACH et al., 2019)

The energy-ecological efficiency was calculated through the Eq. (20) proposed by Carneiro and Gomes (2019), considering the combustion ignition engine by respective SFM and DFM scenarios, as shown in the graphic 3.

Graphic 3. Energy-ecological efficiency for different fuels in SFM and DFM

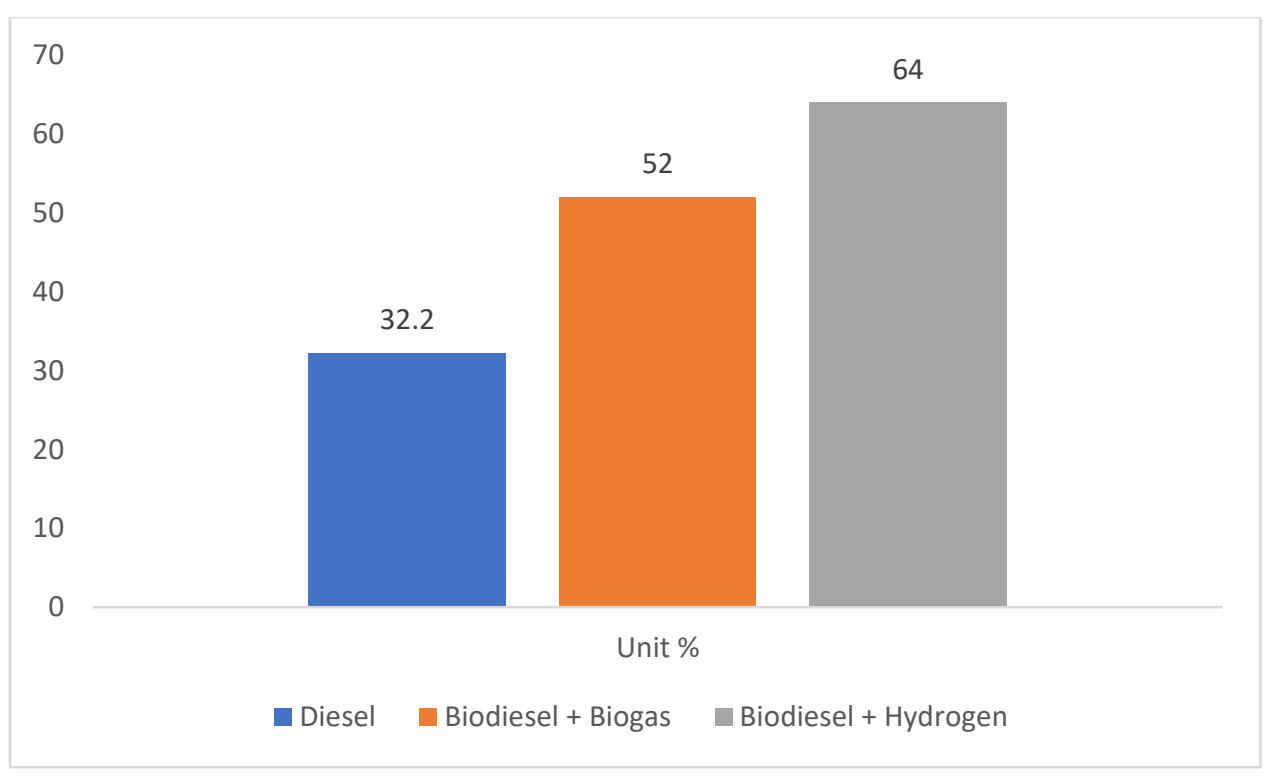

Source: Self-elaboration

671 
As expected, the highest efficiency goes to Biodiesel+Hydrogen scenario, with $64 \%$. Having a poor mixture of fuel and air, the internal combustion of hydrogen does not

674

675 generate emissions of $\mathrm{CO}, \mathrm{CO} 2$ and sulfur dioxide. As for Biodiesel, even with notable amount of emission gases, is still considerably less when compared to diesel fuel.

To BÖRJESSON; MATTIASSON (2008) the more efficient biofuel systems are those based on lignocelluloses and novel conversion technologies. Accordingly LEE et al. (2011) Hydrogen is expected to offer an economically and environmentally more ecoefficient means of transportation. With the help of biofuels the eco-innovation scenario becomes attractive, combines economic advantage with lower ecological-resource burdens and it is generally directed at energy input-substitutes, component recycling, among others.(LEVIDOW et al., 2016)

\subsection{Environmental Life Cycle Costs}

Fuel consumption is an important parameter to assess the viability to replace conventional diesel to biogas-biodiesel or biodiesel-hydrogen proportions in heavy duty trucks operation. From it is possible to estimate heavy duty autonomy by considering the total time travel (in hours). For heavy trucks the ideal average speed is between $80 \mathrm{~km} / \mathrm{h}$ to $88 \mathrm{~km} / \mathrm{h}$. For each $\mathrm{km} / \mathrm{h}$ the fuel consumption will suffer and increase of $1 \%$. If the truck makes an average of $3.36 \mathrm{~km} / 1$ to $88 \mathrm{~km} / \mathrm{h}$ it will go to $2.95 \mathrm{~km} / 1$ to $100 \mathrm{~km} / \mathrm{h}$. As for effect engine, if the truck assumes the velocity at $96 \mathrm{Km} / \mathrm{h}$ the vehicle will require $73 \%$ more engine power than the power required for the ideal speed. Analyzing by maintenance aspect, at $112 \mathrm{~km} / \mathrm{h}$ the tires wear tread will be folded and the increase on maintenance cost will be by $80 \%$. The increase in speed for operational gain does not pay off. The costs, in addition to the higher fuel consumption that immediately observed, will also appear in the increase of maintenance and in the reduction of the useful life of the engine (Ministério da infraestrutura,2013).

According to $(\mathrm{CNT}, 2019)$, the Brazilian national transport confederation, in annual report of survey truckers' profile, truck drivers work on average of more than 8 thousand $\mathrm{km} / \mathrm{month}$.

Having a holistic evaluation of the economic and environmental impacts of a technology, for the calculation purpose, a more simplified analysis of the heavy-duty life 
cycle was adopted, considering the TTW emissions. This internationally recognized assessment tool helps to inform decision makers, allowing them to identify the impacts of new products.

The calculation of the environmental life cycle cost for heavy-duty considers the capital cost, operational cost and replacing technology cost. The truck lifetime adopted is 20 years (EL HANNACH et al., 2019).Interest rate determined through SELIC rate estimated as 2.75 per year on date of May first, 2021 (Banco Central,2021).

The replacing technology cost was disregarded for this study, since it only considerers replacement of components necessary for electric vehicle operation or use of fuel cells due to the need of substitution time at time.(LAJUNEN; LIPMAN, 2016a)

The fixed values considered for calculations related to the environmental cost of the truck life cycle operating in dual fuel mode and powered by soybean biodieselsugarcane biogas and soybean biodiesel-hydrogen produced through electrolysis with photovoltaic energy, electrolysis with wind energy, methane steam reforming without CCUS and biomass gasification, as well reference values of diesel are presented in Table 10 with parameters, values, units and source in line with literature and official data.

\begin{tabular}{|c|c|c|c|}
\hline Parameters & Unit & Value & Reference \\
\hline $\mathrm{CO} 2$ cost & Euro/ton & 47.82 & Investing.com (2021) \\
\hline Medium Cost Biodiesel & $\mathrm{R} \$ / \mathrm{l}$ & 3.53 & $\begin{array}{l}\text { Ministério de minas e } \\
\text { energia }\end{array}$ \\
\hline Medium Cost Diesel & $\mathrm{R} \$ / 1$ & 4.37 & $\operatorname{ANP}(2021)$ \\
\hline $\begin{array}{l}\text { Medium Cost Hydrogen Electrolysis with } \\
\text { Photovoltaic energy }\end{array}$ & $\mathrm{US} \$ / \mathrm{kg}$ & 14.77 & EPE (2021) \\
\hline $\begin{array}{c}\text { Medium Cost Hydrogen } \\
\text { Electrolysis with wind energy }\end{array}$ & $\mathrm{US} \$ / \mathrm{kg}$ & 5.96 & EPE (2021) \\
\hline $\begin{array}{l}\text { Medium Cost Hydrogen Methane steam } \\
\text { reform without CCUS }\end{array}$ & $\mathrm{US} \$ / \mathrm{kg}$ & 2.05 & EPE (2021) \\
\hline Medium Cost Hydrogen biomass gasification & $\mathrm{US} \$ / \mathrm{kg}$ & 2.38 & EPE (2021) \\
\hline Biogas Cost (RJ TAX) & $\mathrm{R} \$ / \mathrm{MWh}$ & 663 & Aneel (2020) \\
\hline Biogas Factor emission & $\begin{array}{c}\mathrm{kgCo} 2 / \mathrm{kg} \\
\mathrm{BG}\end{array}$ & 1.61571 & stechiometric balance \\
\hline Biodiesel factor emission & $\begin{array}{l}\mathrm{kgCo} 2 / \mathrm{kg} \\
\mathrm{BD}\end{array}$ & 2.828 & stechiometric balance \\
\hline Hydrogen Factor emission & $\begin{array}{l}\mathrm{kgCo} 2 / \mathrm{kg} \\
\mathrm{H} 2\end{array}$ & 0 & stechiometric balance \\
\hline
\end{tabular}




\begin{tabular}{|cccc|} 
& $\mathrm{kgCo} / \mathrm{kg}$ & & \\
Diesel Factor Emission & $\mathrm{D}$ & 3.087 & stechiometric balance \\
\hline GNV adaptation cost & $\%$ & 10 & $\begin{array}{c}\text { (LAJUNEN; LIPMAN, } \\
\text { 2016a) }\end{array}$ \\
\hline SELIC & $\%$ & 2.75 & bcb.gov.br \\
\hline Truck Capital Cost & $\mathrm{R} \$$ & $\begin{array}{c}138.263 \\
, 00\end{array}$ & tabelafipebrasil.com \\
\hline Maintenance Cost & & & (LAJUNEN; LIPMAN, \\
& Euro/km & 0.16 & 2016) \\
\hline
\end{tabular}

721

722

723

724

725

726

727

728

729

730

731

732

733
Source: Self-elaboration

For Capital cost to power the engine with biodiesel-biogas and biodiesel-hydrogen proportions, was considered the truck adapted trough natural gas kit, since the technology similarity and for the engine powered only with diesel fuel, the truck market price was stipulated. In extend, the capital costs presented were adjusted by the correction factor previously considered.

The diesel, biodiesel, biogas and hydrogen emission factor were established trough equation (24). $\mathrm{CO} 2$ emissions for diesel, biogas and biodiesel in $\mathrm{kgCO} 2 / \mathrm{h}$ according to the respective flow rates in $\mathrm{kg} / \mathrm{h}$ in SFM and DFM, result in a CO2 cost of $\mathrm{R} \$ / \mathrm{h}$ established by eq. (23) as shown in Table 11.

Table 11: Emission and CO2 emission cost for SFM and DFM scenarios

\begin{tabular}{|c|cc|cc|cc|}
\hline \multicolumn{2}{|c|}{ Scenario } & \multicolumn{2}{c}{ MFR } & \multicolumn{2}{c|}{ Emission } & \multicolumn{2}{c|}{ Emission Cost } \\
\hline $\begin{array}{c}\text { SFM } \\
\text { (Diesel) }\end{array}$ & 33.88 & $\mathrm{~kg} / \mathrm{h}$ & 104.59 & $\mathrm{~kg} \mathrm{CO}_{2} / \mathrm{h}$ & 32.61 & $\mathrm{R} \$ / \mathrm{h}$ \\
$\mathrm{BG}$ & & & & & & \\
Dual & 62.86 & $\mathrm{~kg} / \mathrm{h}$ & 177.8 & $\mathrm{~kg} \mathrm{CO} / \mathrm{h}$ & 54.44 & $\mathrm{R} \$ / \mathrm{h}$ \\
$\mathrm{BD}$ & 26.94 & $\mathrm{~kg} / \mathrm{h}$ & & & & \\
Dual & & & & & & \\
$\mathrm{H} 2$ Dual & 15.06 & $\mathrm{~kg} / \mathrm{h}$ & 18.28 & $\mathrm{~kg} \mathrm{CO}_{2} / \mathrm{h}$ & 5.70 & $\mathrm{R} \$ / \mathrm{h}$ \\
BD & 6.45 & $\mathrm{~kg} / \mathrm{h}$ & & & & \\
Dual & 6.45 & & & & \\
\hline
\end{tabular}

Source: Self-elaboration 
Table 12 presents the values for energy cost, maintenance cost, Co2 cost and capital cost in $\mathrm{R} \$ / \mathrm{km}$ for a truck operating in single and dual fuel mode fueled with diesel, biodiesel-biogas and biodiesel-hydrogen proportions, with 20 years as lifetime and 80 $\mathrm{km} / \mathrm{h}$ as average speed on the road. This study adopted a period of 12-hour workday according to the law $13.103 / 2015$.

Table 12: Heavy duty energy cost, maintenance cost,Co2 cost and capital cost in $\mathrm{R} \$ / \mathrm{Km}$

\begin{tabular}{|c|c|c|c|}
\hline Parameters & Value & Unit & Reference \\
\hline Cco2 Diesel & 32.61 & $\mathrm{R} \$ / \mathrm{km}$ & Equation (23) \\
\hline $\mathrm{Cco} 2 \mathrm{BD}+\mathrm{BG}$ & 56.31 & $\mathrm{R} \$ / \mathrm{km}$ & Equation (23) \\
\hline $\mathrm{Cco} 2 \mathrm{BD}+\mathrm{H} 2$ & 5.69 & $\mathrm{R} \$ / \mathrm{km}$ & Equation (23) \\
\hline Cn Diesel & 2.16 & $\mathrm{R} \$ / \mathrm{km}$ & $\operatorname{ANP}(2021)$ \\
\hline Cn BD & 1.69 & $\mathrm{R} \$ / \mathrm{km}$ & Ministério de minas e energia \\
\hline $\mathrm{Cn} \mathrm{H} 2 \mathrm{PV}$ & 14.74 & $\mathrm{R} \$ / \mathrm{km}$ & EPE $(2021)$ \\
\hline $\mathrm{Cn} \mathrm{H} 2 \mathrm{WE}$ & 5.95 & $\mathrm{R} \$ / \mathrm{km}$ & EPE (2021) \\
\hline $\mathrm{Cn}$ H2 VR w/ CCUS & 2.04 & $\mathrm{R} \$ / \mathrm{km}$ & EPE (2021) \\
\hline Cn H2 Bio G. & 2.37 & $\mathrm{R} \$ / \mathrm{km}$ & EPE (2021) \\
\hline $\mathrm{Cn} B \mathrm{~B}$ & 3.39 & $\mathrm{R} \$ / \mathrm{km}$ & Aneel (2020) \\
\hline Ccap SFM & $138.263,00$ & $\mathrm{R} \$ / \mathrm{km}$ & tabelafipebrasil.com \\
\hline Ccap SFM +GNV & $152.089,30$ & $\mathrm{R} \$ / \mathrm{km}$ & $\begin{array}{c}\text { tabelafipebrasil.com } \\
\text { (LAJUNEN; LIPMAN, 2016) }\end{array}$ \\
\hline $\mathrm{Cm}$ & 1.01 & $\mathrm{R} \$ / \mathrm{km}$ & (LAJUNEN; LIPMAN, 2016) \\
\hline
\end{tabular}

743

Thus, with ( $\mathrm{j}$ ) values ranging from 1 to 20 years (heavy duty lifetime) it is possible to estimate the Environmental Life Cycle Costing. DFM scenarios. 
751

\section{CeLC}

12.00

10.00

8.00

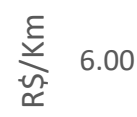

4.00

2.00

0.00

$\square$ Diesel $\square \mathrm{BD}+\mathrm{BG} \square \mathrm{BD}+\mathrm{H} 2 \mathrm{PV} \square \mathrm{BD}+\mathrm{H} 2 \mathrm{WE} \square \mathrm{BD}+\mathrm{H} 2 \mathrm{MSR}$ W/CCUS $\square \mathrm{BD}+\mathrm{H} 2 \mathrm{Biog}$
10.21

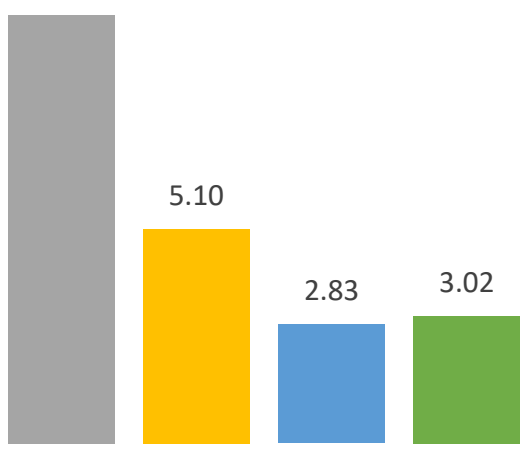

Source: Self-Elaboration

In the context of the global concern with the decarbonization of energy production and consumption systems, its transformation with hydrogen as the main energy vector has led to the search for diversity of hydrogen produced according to production origin, in this way, the calculation of Hydrogen produced through electrolysis with photovoltaic energy, electrolysis with wind energy, methane steam reforming without CCUS and biomass gasification became necessary.

In turn, the differentiation of hydrogen by carbon content associated with its production has distinct consequences in terms of contributions to the mitigation of greenhouse gases emissions and prevention of global climate change. Therefore, it is necessary to distinguish this production origin through the use of classifications with reference to color distinction.(EPE, 2021b)

Brown or black hydrogen is produced from coal without carbon capture, utilization and sequestration. Gray hydrogen is generated from natural gas without carbon capture, utilization and sequestration. Blue hydrogen refers to production from natural gas, but with without carbon capture, utilization and sequestration and it is occasionally used to name hydrogen generated from other fossil fuels with carbon capture, utilization and sequestration. Finally, Green hydrogen has been defined as the one produced from variable renewable sources (EPE, 2021b). 
Photovoltaic energy and wind energy are the fastest growing renewable energies in the Brazilian energy matrix, representing a growth of $92.2 \%$ and $15.5 \%$ respectively, in 2019 when compared to the year 2018.(EPE, 2020).Biomass gasification justified by the potential of biomass residues for production in Brazil, especially advance in the offer of biomass from sugarcane representing an increase of $5.9 \%$ of energy consumption in 2019 when compared to 2018 and in particular, it points to a strategy that takes advantage of Brazil's competitive advantages (EPE, 2021b). Methane steam reforming without CCUS, belonging to the gray hydrogen category, is the most used route production in industrial terms since it is two to three times less expensive to deliver then green hydrogen. (IRENA, 2020)

Under analysis against the four types of hydrogen as to its origin of production, the methane steam reforming without CCUS presents the smallest $\mathrm{C}_{\mathrm{eLC}}$ worth, followed by biomass gasification, electrolysis with wind energy and electrolysis with photovoltaic energy respectively. In fact, the lowest hydrogen production costs are currently observed in the steam reforming of methane, which is consistent with a technological route based on fossil energy sources. The electrolysis of water using renewable wind and solar sources is the most expensive technological route among those already available on the market. Biomass gasification is not yet a mature technology, but it is estimated that by 2042 this route will allow competitive hydrogen production costs.(EPE, 2021b)

The scenario that would be easier to develop new markets because it is currently dominant and more competitive is the Methane steam reforming without CCUS. However, this route will face risks in the future related to possible restrictions in a scenario of deep decarbonization and an accelerated drop in the costs of water electrolysis based on variable renewables such as wind and solar. On the other hand, the scenarios of electrolysis with photovoltaic energy, electrolysis with wind energy, methane steam and biomass gasification are still less competitive, however, they present great opportunities in the future in a state of accelerating cost reduction of investment in electrolysis and generation electric with variable renewables and biomass gasification.

Diesel Scenario has the lowest value of $\mathrm{C}_{\mathrm{eLC}}$ since there is no need to suffer engines' adaptation costs, is powered by a fuel that has national policy and therefore contains value consistent with the market. Biodiesel+ Biogas has the value duo to necessity of engines adaptations, highest emission cost and market fuel price close to diesel value. 
The development of renewable fuels is on the agenda of several countries, being a safe alternative to guarantee economic development and energy security. In the case of Brazil, it has policies such as ProAlcool, RenovaBio and National Biodiesel Production and Use Program (PNB) but still lacks when it comes to national public policy for Biogas and Hydrogen. Currently there is a processing bill 2193/20 which creates a federal Policy on Biogas and Biomethane and intends to increase investments in infrastructure for the production, distribution, and commercialization of biogas, biomethane and biofertilizer. (Brasil,2020). As for Hydrogen, there is no specific norm from the National Electric Energy Agency (ANEEL) or the National Petroleum, Natural Gas and Biofuels Agency (ANP) that regulates production, storage and transportation of hydrogen for energy uses, demonstrating the need for diversification and encouragement of the Brazilian energy matrix.

Currently, $99 \%$ of the hydrogen used as fuel is produced from non-renewable sources. and less than $0.1 \%$ is produced through water electrolysis, according (IEA,2021). Brazil, as one of the biggest producers of biofuels and holder of a renewable energy matrix, can become one of the major players in this market. As a promise for the future, green hydrogen is a fuel with high potential for use in power generation and consequently to use in transport sectors, as it is obtained from renewable sources, in a process in which there is no carbon emission.

The reduction in GHG emissions obtained when partially displacing diesel with hydrogen is much higher than the reductions obtained using CNG or LNG as fuel for heavy duty trucks and according to (EL HANNACH et al., 2019) although the LCC results were favorable for the dual-fuel configuration, the actual impact of introducing hydrogen on the emission of certain components, such as NOx. The reduction of emissions and operating costs, combined with the minimal conversion process of existing trucks from diesel to dual-fuel mode, constitute a major advantage of this technology in comparison to the other available alternatives.

It remains the case of DFM vehicles powered by biofuels are the most competitive choice in relation to conventional diesel engine, along with CNG where natural gas is relatively inexpensive, but their dependence on fossil fuels and their pollutant emissions profile weakens their competitiveness in the future.(LAJUNEN; LIPMAN, 2016). 
The first concept to be kept in mind is that, despite the great promise, the principal barriers to the greater use of biofuels in industry are high costs, investors' confidence, competitiveness, and a lack of policy focus. In this context, for a more accurate decisionmaking among the studied scenarios, it is necessary to consider the economic field, as well as the environmental, political, and social ones. Considering the characteristic Brazilian condition and the nature of application of the dual fuel system to road cargo vehicles, is safe to claim the scenario using the proportions of biodiesel and hydrogen produced through biomass gasification as the most promising and efficient. Despite being in third place in the $\mathrm{C}_{\mathrm{eLC}}$ perspective and lack in government policies, since the search for the energy transition is still gradual and depends on technological innovations, in a long term perspective it combines great environmental and social capacities, once Brazil has a great agricultural power and global interest is rising in green hydrogen as one of the solutions for an energy transition toward zero or net-zero emissions, being increasingly socially accepted.

\section{FINAL CONSIDERATIONS}

In summary, the values found for biodiesel-hydrogen and biodiesel-biogas mass flows were $6.45 \mathrm{~kg} / \mathrm{h}$ respectively and $26.94 \mathrm{~kg} / \mathrm{h}$. The conventional Diesel mass flow were $33.88 \mathrm{~kg} / \mathrm{h}$ as shown in the graphic 5 . Through implement of energy ecological method, the highest value of Fco2 was found for Diesel fuel, due to the greater number of moles of $\mathrm{CO}_{2}$ resulting from its combustion, with insignificant values of $\mathrm{CH} 4$ and $\mathrm{CO}_{2}$. On the other hand, Biodiesel presented the highest value of f1.4 DCB eq due to the NOx emissions increase in 5\%. Under operating mode scenario analysis, the proportions of Biodiesel and hydrogen presents the smallest amount of $\mathrm{Fco}_{2}$ among the two dual fuel scenarios but at the same time, has the biggest value when it comes to F1.4 $4_{\mathrm{ADCBeq}}$ emissions. This is due to hydrogen, responsible for $70 \%$ of the Dual Fuel mode. Hydrogen system has emissions close to zero $\mathrm{CO} 2$ but at the same time, it has a considerable proportion of NOx, which ends up influencing the $\mathrm{F}_{1.4 \mathrm{ADCBeq}}$ final calculation. The best setup from the ecological standpoint is for Biodiesel + Biogas and Biodiesel + Hydrogen with equal values of II, however, in a closer analysis of IIGW and IIHT values it is possible to notice a significant decrease in emissions from the Biodiesel + Hydrogen 
proportions and as expected,, the highest efficiency goes to Biodiesel+Hydrogen operation mode, with $64 \%$.

Aligning all discoveries and considering the characteristic Brazilian condition and the nature of application of the dual fuel system to road cargo vehicles, is safe to claim the scenario using the proportions of biodiesel and hydrogen produced through biomass gasification as the most promising and efficient. Despite being in third place in the $\mathrm{C}_{\mathrm{eLC}}$ perspective and lack in government policies, since the search for the energy transition is still gradual and depends on technological innovations, in a long-term perspective it combines great environmental with greater energy-ecological efficiency and social capacities, once Brazil has a great agricultural power and global interest is rising in green hydrogen as one of the solutions for an energy transition toward zero or net-zero emissions, being increasingly socially accepted.

The findings we presented will assist as a baseline for future developments in compression ignition engine fueled with liquid-gas fuel proportions field. Being a relatively young and emerging research area, there is still a big absence of economic and energy-ecological efficiency estimative studies in this context, therefore, the data contained in this study will open space for new research opportunities, assist practical application of these concepts, aggregate valuable information and promote better understand of science. Recapping this analysis in the future would offer perception into how this field, and possibly scientific research in general, evolves over time.

The authors are very grateful to the financial support provided by the Brazilian National Council for Scientific and Technological Development $(\mathrm{CNPq})$, Grant Number 406789/2018-5 and are financed in part by the Coordenação de Aperfeiçoamento de Pessoal de Nível Superior-Brasil (CAPES)-Finance Code 001.

\section{REFERENCES}

ALOUCHEK, F. Z. et al. Experimental investigation of the equivalence ratio influence 
on combustion, performance and exhaust emissions of a dual fuel diesel engine operating on synthetic biogas fuel. Energy Conversion and Management, v. 152, n. August, p. 291-299, 2017.

BORA, B. J. et al. Effect of compression ratio on performance, combustion and emission characteristics of a dual fuel diesel engine run on raw biogas. Energy Conversion and Management, v. 87, p. 1000-1009, 2014.

BORA, B. J.; SAHA, U. K. Experimental evaluation of a rice bran biodiesel - biogas run dual fuel diesel engine at varying compression ratios. Renewable Energy, v. 87, p. 782$790,2016$.

BÖRJESSON, P.; MATTIASSON, B. Biogas as a resource-efficient vehicle fuel. Trends in Biotechnology, v. 26, n. 1, p. 7-13, 2008.

CÂRDU, M.; BAICA, M. A seismic vision regarding a methodology to estimate globally the energy-ecologic efficiency of thermopower plants (TPPs). Energy Conversion and Management, v. 42, n. 11, p. 1317-1325, 2001.

CARNEIRO, M. L. N. M.; GOMES, M. S. P. Energy-ecologic efficiency of waste-toenergy plants. Energy Conversion and Management, v. 195, n. May, p. 1359-1370, 2019.

CORONADO, C. R. et al. Determination of ecological efficiency in internal combustion engines: The use of biodiesel. Applied Thermal Engineering, v. 29, n. 10, p. 18871892, 2009a.

CORONADO, C. R. et al. Determination of ecological efficiency in internal combustion engines: The use of biodiesel. Applied Thermal Engineering, v. 29, n. 10, p. 18871892, 2009b.

CORONADO, C. R.; DE CARVAlHO, J. A.; SILVEIRA, J. L. Biodiesel CO2 emissions: A comparison with the main fuels in the Brazilian market. Fuel Processing Technology, v. 90, n. 2, p. 204-211, 2009.

DEHERI, C. et al. A review on performance of biogas and hydrogen on diesel engine in dual fuel mode. Fuel, v. 260, n. May 2019, p. 116337, 2020.

EL HANNACH, M. et al. Life cycle assessment of hydrogen and diesel dual-fuel class 8 heavy duty trucks. International Journal of Hydrogen Energy, v. 44, n. 16, p. 8575- 
927 EPE. Balanço Energético Nacional 2020: Relatório síntese, ano base 2019.Ben 2020.

928 [s.l: $\quad$ s.n.]. Disponível em: <https://www.epe.gov.br/sites-pt/publicacoes-dados929 abertos/publicacoes/PublicacoesArquivos/publicacao-479/topico-521/Relatório Síntese 930 BEN 2020-ab 2019_Final.pdf\%0Ahttps://www.epe.gov.br/pt/publicacoes-dados931 abertos/publicacoes/balanco-energetico-naciona>.

932 EPE. BEN 2021 Relatório Síntese. [s.l: s.n.]. Disponível em: $933<$ https://www.epe.gov.br/pt/publicacoes-dados-abertos/publicacoes/balanco-energetico934 nacional-2021>.

935 EPE. Bases para a Consolidação da Estratégia Brasileira do HidrogênioBases para 936 a Consolidação da Estratégia Brasileira do Hidrogênio. [s.l: s.n.]. Disponível em: $937<$ https://www.epe.gov.br/sites-pt/publicacoes-dados938 abertos/publicacoes/PublicacoesArquivos/publicacao-569/Hidrogênio_23Fev2021NT 939 (2).pdf>.

940 HOSSEINI, S. M.; AHMADI, R. Performance and emissions characteristics in the 941 combustion of co-fuel diesel-hydrogen in a heavy duty engine. Applied Energy, v. 205, 942 n. August, p. 911-925, 2017.

943 INMETRO. Programa brasileiro de etiquetagem. [s.l: s.n.].

944 IRENA. GREEN HYDROGEN: A GUIDE TO POLICY MAKING. [s.l: s.n.].

945 IRENA. World energy transitions outlook. [s.l: s.n.].

946 KHATRI, N.; KHATRI, K. K. Hydrogen enrichment on diesel engine with biogas in dual 947 fuel mode. International Journal of Hydrogen Energy, v. 45, n. 11, p. 7128-7140, 9482020.

949 KHAYUM, N.; ANBARASU, S.; MURUGAN, S. Combined effect of fuel injecting 950 timing and nozzle opening pressure of a biogas-biodiesel fuelled diesel engine. Fuel, v. 951 262, n. May 2019, p. 116505, 2020.

952 KORAKIANITIS, T.; NAMASIVAYAM, A. M.; CROOKES, R. J. Natural-gas fueled 953 spark-ignition (SI) and compression-ignition (CI) engine performance and emissions. 954 Progress in Energy and Combustion Science, v. 37, n. 1, p. 89-112, 2011. 
LAJUNEN, A.; LIPMAN, T. Lifecycle cost assessment and carbon dioxide emissions of diesel, natural gas, hybrid electric, fuel cell hybrid and electric transit buses. Energy, v. 106, p. 329-342, 2016 a.

LAJUNEN, A.; LIPMAN, T. Lifecycle cost assessment and carbon dioxide emissions of diesel, natural gas, hybrid electric, fuel cell hybrid and electric transit buses. Energy, v. 106, p. 329-342, 2016b.

LEE, J. Y. et al. Eco-efficiency of $\mathrm{H} 2$ and fuel cell buses. International Journal of Hydrogen Energy, v. 36, n. 2, p. 1754-1765, 2011.

LEVIDOW, L. et al. Process eco-innovation: Assessing meso-level eco-efficiency in industrial water-service systems. Journal of Cleaner Production, v. 110, p. 54-65, 2016.

MOURAD, A. L.; WALTER, A. The energy balance of soybean biodiesel in Brazil: a case study. Biofuels, Bioproducts and Biorefining, v. 5, n. 3, p. 185-197, 2011.

NADALETTI, W. C. et al. Potential use of landfill biogas in urban bus fleet in the Brazilian states: A review. Renewable and Sustainable Energy Reviews, v. 41, p. 277283, 2015.

RIMKUS, A.; STRAVINSKAS, S.; MATIJOŠIUS, J. Comparative study on the energetic and ecologic parameters of dual fuels (diesel-NG and HVO-biogas) and conventional diesel fuel in a CI engine. Applied Sciences (Switzerland), v. 10, n. 1, 2020.

ROSHA, P. et al. Impact of compression ratio on combustion behavior of hydrogen enriched biogas-diesel operated CI engine. Fuel, v. 310, n. PB, p. 122321, 2022.

SARKAR, A.; SAHA, U. K. Role of global fuel-air equivalence ratio and preheating on the behaviour of a biogas driven dual fuel diesel engine. Fuel, v. 232, n. May, p. 743754, 2018.

SARKAR, A.; SAHA, U. K. Energetic and Exergetic Analyses of a Dual-Fuel Diesel Engine Run on Preheated Intake Biogas-Air Mixture and Oxygenated Pilot Fuels. Journal of Energy Engineering, v. 146, n. 5, p. 04020046, 2020.

SIDIBÉ, S. S. et al. Use of crude filtered vegetable oil as a fuel in diesel engines state of the art: Literature review. Renewable and Sustainable Energy Reviews, v. 14, n. 9, p. 2748-2759, 2010. 
985 SOLAYMANI, S.; SHARAFI, S. A comparative study between government support and 986 energy efficiency in malaysian transport. Sustainability (Switzerland), v. 13, n. 11, p. $9871-15,2021$.

988 VERMA, S. et al. A renewable pathway towards increased utilization of hydrogen in 989 diesel engines. International Journal of Hydrogen Energy, v. 45, n. 8, p. 5577-5587, 9902020.

991 VWCO. Volkswagen Caminhões e ônibus: Família Volksbus - Linha Urbano.

992 WONG, K. I. et al. Sparse Bayesian extreme learning machine and its application to 993 biofuel engine performance prediction. Neurocomputing, v. 149, n. Part A, p. 397-404, 9942015. 